\title{
Mirosław Wasilewski
}

Szkoła Główna Gospodarstwa Wiejskiego w Warszawie

e-mail: miroslaw_wasilewski@sggw.pl

ORCID: 0000-0001-6791-5713

\section{Magdalena Pawlik}

Państwowa Szkoła Wyższa im. Papieża Jana Pawła II w Białej Podlaskiej

e-mail: magdalenahodun@o2.pl

ORCID: 0000-0003-3236-5111

\section{ŹRÓDŁA FINANSOWANIA DZIAŁALNOŚCI \\ PRZEDSIĘBIORSTW PRZEMYSLOWYCH \\ W OPINII ZARZĄDZAJĄCYCH}

\section{SOURCES OF FINANCING OF INDUSTRIAL} ENTERPRISES ACCORDING TO THEIR MANAGERS

DOI: $10.15611 / \mathrm{pn} .2018 .533 .22$

JEL Classification: G32

Streszczenie: W opracowaniu przedstawiono opinie zarządzających dotyczące źródeł finansowania działalności w przedsiębiorstwach przemysłowych. Analizie poddano 26 spółek produkcyjnych notowanych na Giełdzie Papierów Wartościowych w Warszawie. Przedsiębiorstwa przemysłowe stosują zróżnicowane formy finansowania działalności, biorąc pod uwagę ich dostępność oraz koszt zaangażowania. Najwięcej spółek korzysta z kapitału własnego i długoterminowych kredytów bankowych. Te źródła finansowania są stabilne, aczkolwiek najdroższe. Za najtrudniej dostępne źródła finansowania zarządzający uznali dotacje i subwencje oraz venture capital, $\mathrm{z}$ których nie korzystało żadne $\mathrm{z}$ badanych przedsiębiorstw.

Słowa kluczowe: przedsiębiorstwa przemysłowe, źródła finansowania, strategia gospodarowania kapitałem obrotowym, rentowność kapitałów własnych.

Summary: The article presents the managers' opinions on shaping financing sources of industrial enterprises business. Twenty six industrial enterprises listed on the Warsaw Stock Exchange have been analyzed. The industrial companies use different forms of financing, taking into account their availability and cost of investment. The most of all companies use equity and long-term bank loans. These liabilities are stable, although they are the most expensive financing sources. For the least available financing sources managers considered subsidies, subventions and venture capital, which are not used by any surveyed enterprise.

Keywords: industrial enterprises, sources of financing, working capital management strategy, return on equity. 


\section{Wstęp}

Prowadzenie działalności gospodarczej nie jest możliwe bez posiadania odpowiedniego poziomu kapitału. W każdym przedsiębiorstwie w procesie zarządzania dobór właściwych źródeł finansowania stanowi niezwykle istotny aspekt działalności [Waga 2014, s. 2]. Struktura tych źródeł może wpływać na bieżącą kondycję finansową i na wartość przedsiębiorstwa [Gawrońska, Makarska 2012, s. 45].

W literaturze przedmiotu determinanty struktury kapitałowej określane są przez teorie rynku zarówno doskonałego, jak i niedoskonałego. Jedną z podstawowych teorii rynku doskonałego jest ta nieuwzględniająca podatku dochodowego, stworzona przez Millera i Modiglianiego, według której średni koszt kapitału przedsiębiorstwa nie zależy od struktury kapitałowej [Modigliani, Miller 1958, s. 268-269]. Teorie rynku doskonałego stanowią podstawę do formułowania dalszych teorii struktury kapitałowej. Chociaż teorie te mają hipotetyczny charakter, są punktem odniesienia dla zdecydowanej większości pozostałych nurtów teorii struktury kapitałowej w teoriach rynku niedoskonałego [Gajdka 2002, s. 65-66].

Według teorii podatkowych w gospodarce, w której obowiązują podatki, wartość przedsiębiorstwa zwiększa się wraz ze wzrostem udziału zadłużenia w pasywach ogółem [Gajdka, Walińska 1998, s. 188-198]. W przedsiębiorstwach charakteryzujących się wysokim poziomem nieodsetkowych tarcz podatkowych uzyskiwane są mniejsze korzyści podatkowe wynikające $\mathrm{z}$ finansowania działalności kapitałem obcym [Gajdka 2002, s. 150]. Nieodestkowa tarcza podatkowa powoduje, że korzyści z finansowania kapitałem obcym wzrastają wolniej w relacji do poziomu zaciągniętego zadłużenia. Nie zmienia to jednak faktu, że inflacja zwiększa korzyści z finansowania zewnętrznego [Gajdka 2002, s. 157].

Korzystanie przez przedsiębiorstwo z kapitałów obcych przyczynia się do uzyskiwania korzyści $w$ formie odsetkowych tarcz podatkowych, jednakże potęguje koszty w formie kosztów bankructwa oraz kosztów agencji. Według teorii substytucji dotyczącej kosztów bankructwa, przedsiębiorstwa charakteryzujące się wysokim ryzykiem finansowym powinny ograniczać korzystanie z obcych źródeł finansowania, natomiast te o niskim ryzyku finansowym - zwiększać zadłużenie do momentu, gdy oczekiwane koszty bankructwa zrekompensują korzyści podatkowe, wynikające z zaciągania długu [Myers 1984, s. 580-581]. Zgodnie z teorią agencji zastępowanie kapitału własnego kapitałem obcym jest opłacalne, dopóki korzyści z tego tytułu m.in. w postaci odsetkowej tarczy podatkowej, przewyższają zagrożenia wynikające z wysokiego poziomu zadłużenia (koszty bankructwa, koszty agencyjne długu) [Błach 2009, s. 99].

Teorie statyczne poszukują optymalnej struktury kapitałowej, przy określonej stałej wartości pasywów niezbędnych do finansowania działalności. Teorie dynamiczne, do których zaliczana jest m.in. asymetria informacji, zakładając zmienność wielkości dostępnego kapitału, ustalają właściwą kolejność wykorzystania kapitałów. Zgodnie z teorią hierarchii źródeł finansowania przedsiębiorstwa w pierwszej 
kolejności finansują swoją działalność kapitałem własnym, następnie kapitałem obcym, a w ostateczności zewnętrznym kapitałem własnym w formie akcji [Myers 1984, s. 581]. Przykładem pozostałych teorii dynamicznych jest m.in. teoria uwzględniająca cykl życia przedsiębiorstwa, w której każda faza rozwoju wymaga określonej struktury finansowania [Churchill, Lewis 1983, s. 30-50].

Analizując teorie struktury kapitału, można stwierdzić, iż na wybór sposobu finansowania wpływają różnorodne czynniki i nie można jednoznacznie określić, w jaki sposób ustalić optymalny poziom zadłużenia. Damodaran [2007, s. 868] zauważa, że zarządzający, wybierając strukturę finansowania przedsiębiorstw, rzadko kierują się analizą kosztów i korzyści z tym związanych. Struktura zadłużenia częściej wynika z czynników nieobiektywnych.

Duliniec [2007, s. 77] podkreśla, iż jednostki gospodarcze szukają kompromisu między maksymalizacją korzyści podatkowych i minimalizacją kosztów trudności finansowych, który zapewni optymalną z punktu widzenia wartości przedsiębiorstwa strukturę kapitału, czyli taką, przy której wartość rynkowa przedsiębiorstwa jest najwyższa, a średni ważony koszt kapitału najniższy. Wędzki [2003, s. 134] twierdzi, iż finansowanie majątku kapitałami stałymi ogranicza ryzyko i zapewnia całkowite bezpieczeństwo finansowe, aczkolwiek powoduje wzrost kosztów kapitału i obniżenie stopy zwrotu, ze względu na konieczność utrzymywania odpowiednich rozmiarów źródeł finansowania. Wasilewski i Zabadała [2015, s. 487] podkreślają, iż tylko nieliczni zarządzający przedsiębiorstwami rolniczymi uważają finansowanie działalności wyłącznie kapitałem własnym jako korzystne dla tych jednostek gospodarczych. Główną wadą samofinansowania jest ograniczona możliwość zakupu nowoczesnych środków trwałych, spowodowana brakiem posiadania wystarczającej ilości kapitału. Finansowanie działalności kapitałem własnym jest szczególnie ważne w małych i średnich przedsiębiorstwach, w których zarządzający mają na ogół problemy z pozyskaniem kredytów bankowych. W tym przypadku to kapitał własny wydatnie określa możliwości rozwojowe tych przedsiębiorstw [Wasilewski, Pisarska 2009, s. 221].

Według Zalewskiego [1998, s. 50-51] zarządzający przedsiębiorstwami, ustalając źródła finansowania, kierują się maksymalizacją wartości dla właścicieli. W związku z tym kapitały stałe powinny finansować jedynie aktywa trwałe. Majątek obrotowy, ze względu na krótki czas zaangażowania w jednostce gospodarczej, powinien być finansowany zobowiązaniami. Bartkiewicz [2004, s. 51] podkreśla, iż krótkoterminowe finansowanie jest tańsze od długoterminowego, ze względu na różnice stóp procentowych i bardziej elastyczne, ponieważ wartość zobowiązań krótkookresowych może być stosunkowo łatwo zmniejszona lub zwiększona w zależności od potrzeb jednostki gospodarczej. Wędzki [2003, s. 136] zauważa, iż „efektem preferowania zobowiązań krótkoterminowych jest większe ryzyko utraty płynności, co w konsekwencji może doprowadzić do upadłości przedsiębiorstwa. Ponadto krótkoterminowe stopy procentowe wykazują tendencję do częstszych zmian. W strukturze zobowiązań bieżących, jako podstawowego źródła pochodzenia aktywów obroto- 
wych, powinno się wykorzystywać zobowiązania generujące odsetki, ponieważ pozwalają one na osiągnięcie dodatniego efektu dźwigni finansowej. Należy redukować natomiast wartość zobowiązań z tytułu dostaw i usług oraz wekslowych". Czekaj i Dresler [2005, s. 133] stwierdzają, iż finansowanie przedsiębiorstwa, zarówno przez kapitały stałe, jak i zobowiązania bieżące, prowadzi do optymalnych rezultatów. Pozwala bowiem na minimalizację ryzyka związanego z utratą płynności finansowej oraz zmniejszenie kosztów zaangażowania kapitału. Zatem dobór odpowiednich źródeł finansowania w dużej mierze determinuje efektywność funkcjonowania podmiotów gospodarczych.

Czynniki decydujące o wyborze struktury kapitału można podzielić na trzy grupy, tj. makroekonomiczne, sektorowe i mikroekonomiczne. Te pierwsze dotyczą aspektów ekonomicznych, prawnych i politycznych. Są niezależne od przedsiębiorstwa i generują ryzyko systematyczne, aczkolwiek ze względu na ich wpływ na kształtowanie się kosztów kapitału powinny być włączone w proces podejmowania decyzji dotyczących finansowania przedsiębiorstwa. Czynniki sektorowe wynikają głównie z różnorodnego poziomu majątku, charakterystycznego dla danej działalności. Przedsiębiorstwa o wyższym udziale aktywów trwałych mają większe możliwości negocjacyjne przy pozyskiwaniu kapitałów obcych, ale charakteryzują się mniejszą elastycznością działania. Wewnętrzne czynniki struktury kapitału należy rozpatrywać indywidualnie z uwzględnieniem ryzyka operacyjnego, które zależy m.in. od udziału kosztów stałych, zmienności popytu, zdolności dostosowania cen sprzedaży do zmian cen czynników produkcji oraz zdolności do rozwijania nowych produktów [Łukasik, Naczyński 2015, s. 77].

\section{Cel i metody badań}

Celem opracowania jest określenie opinii zarządzających w zakresie kształtowania i wyboru źródeł finansowania działalności w przedsiębiorstwach przemysłowych. Zasadnicza uwaga została zwrócona na określenie struktury i dostępności kapitałów oraz kosztów ich zaangażowania. Badania przeprowadzono z wykorzystaniem kwestionariusza wywiadu w latach 2013-2014. Adresatami tych badań byli prezesi zarządów, dyrektorzy finansowi oraz główni księgowi spółek notowanych na Giełdzie Papierów Wartościowych (GPW) w Warszawie, które według klasyfikacji stosowanej na giełdzie zaliczane są do branży przemysłowej. Ostatecznej analizie poddano 26 przedsiębiorstw (przemysł spożywczy - 6 spółek, przemysł motoryzacyjny - 2 spółki, przemysł metalowy - 6 spółek, przemysł materiałów budowlanych -4 spółki, przemysł lekki - 4 spółki, przemysł elektromaszynowy - 4 spółki). Spółki charakteryzowały się zróżnicowanym potencjałem majątkowym i kapitałowym oraz wynikami finansowymi.

Odpowiedzi zarządzających spółkami branży przemysłowej zostały pogrupowane według dwóch kryteriów, tj. wielkości udziału kapitału obrotowego w aktywach oraz poziomu rentowności kapitału własnego (ROE). Przy każdym kryterium grupo- 
wania odpowiedzi zarządzających spółkami giełdowymi dodatkowo zostały podzielone na trzy grupy, z wykorzystaniem metody kwartyli. Do pierwszej grupy (I) zaliczono spółki o wielkościach wskaźnika mniejszych lub równych kwartylowi pierwszemu - dolnemu (25\% badanej zbiorowości - 7 spółek). Druga grupa (II) obejmowała przedsiębiorstwa o wielkościach wskaźnika większych od kwartyla pierwszego i mniejszych od kwartyla trzeciego (50\% badanej zbiorowości - 12 spółek). W skład trzeciej grupy (III) wchodziły przedsiębiorstwa o wskaźniku większym lub równym kwartylowi trzeciemu - górnemu ( $25 \%$ badanej zbiorowości - 7 spółek). W przypadku pierwszego kryterium podziału spółek przyjęto, iż przedsiębiorstwa należące do pierwszej grupy realizowały agresywną strategię zarządzania kapitałem obrotowym, wchodzące w skład drugiej - umiarkowaną, natomiast w skład trzeciej - prowadzące konserwatywną politykę gospodarowania tym kapitałem. W ramach drugiego kryterium grupowania badanych przedsiębiorstw wykorzystywano następujące określenia: grupa I o najniższym poziomie rentowności kapitału własnego, o poziomie przeciętnym (grupa II) oraz wielkości najwyższej (grupa III). Odpowiadając na pytania zarządzający spółkami mieli możliwość wskazania co najmniej jednej odpowiedzi. Dla ułatwienia opisu uzyskanych wyników określenie „procent” (\%) oznaczało procent wskazań. Ponadto niektóre odpowiedzi zostały zakodowane (wskazaniom przypisano wielkości liczbowe), a w tabelach zaprezentowano średnie arytmetyczne ocen. W tabeli 1 przedstawiono liczbę spółek poddanych analizie oraz przedziały wskaźników wybranych kryteriów w poszczególnych grupach przedsiębiorstw.

Tabela 1. Liczba badanych spółek oraz przedziały wskaźników według poszczególnych kryteriów

\begin{tabular}{|l|c|c|c|}
\hline \multicolumn{1}{|c|}{ Kryteria grupowania } & Grupa & Przedziały wskaźników & Liczba spółek \\
\hline \multirow{2}{*}{$\begin{array}{l}\text { Udział kapitału obrotowego } \\
\text { w aktywach (\%) }\end{array}$} & I & $(-12,5)-5,8$ & 7 \\
\cline { 2 - 4 } & II & $6,0-22,5$ & 12 \\
\cline { 2 - 4 } & III & $26,7-56,5$ & 7 \\
\hline \multirow{2}{*}{ ROE (\%) } & I & $(-23,0)-2,1$ & 7 \\
\cline { 2 - 4 } & II & $2,2-8,1$ & 7 \\
\cline { 2 - 4 } & III & $8,7-29,2$ & 26 \\
\hline \multicolumn{4}{|l}{} \\
\hline
\end{tabular}

Źródło: opracowanie własne.

\section{Wyniki badań}

W badanej zbiorowości odnotowano duże zróżnicowanie opinii zarządzających na temat kształtowania źródeł finansowania działalności (tabela 2). Najwięcej przedstawicieli spółek (średnio 88,5\%) wskazało, iż finansuje działalność stabilnymi źródłami finansowania, tj. kapitałem własnym i długoterminowymi kredytami bankowymi. Średnio 84,6\% zarządzających zadeklarowało, iż korzysta z krótkoterminowego 
kredytu bankowego, natomiast $80,8 \%$ z kredytu kupieckiego. Dużym zainteresowaniem cieszyła się również oferta instytucji leasingowej (średnio 53,8\%). Ponadto należy zaznaczyć, iż średnio 42,3\% przedsiębiorstw pozyskało dodatkowe źródło finansowania $\mathrm{w}$ postaci dotacji i subwencji, a więc kapitałów niewymagających zwrotu.

Tylko 57,1\% przedstawicieli spółek, realizujących agresywną strategię gospodarowania kapitałem obrotowym, wskazało kapitał własny jako źródło finansowania działalności. W tym przypadku finansowanie działalności przedsiębiorstw opierało się głównie na środkach pochodzących z kredytów. W spółkach realizujących strategię umiarkowaną i konserwatywną wszyscy zadeklarowali, iż wykorzystują kapitały własne. Ponadto w miarę wzrostu wskaźnika udziału kapitału obrotowego w aktywach malała liczba wskazań, iż kredyt kupiecki jest źródłem finansowania majątku (z 85,7\% do 71,4\%). Przedsiębiorstwa zwiększały wykorzystanie kapitałów stałych, ograniczając tym samym zapotrzebowanie na finansowanie krótkoterminowe, co zmniejszało ryzyko utraty płynności finansowej. Odwrotną zależność odnotowano w przypadku pożyczek, gdyż bardziej rygorystyczna strategia gospodarowania kapitałem obrotowym powodowała wzrost liczby wskazań na to źródło finansowania, z 14,3\% do 28,6\%. W przypadku długo- i krótkoterminowych kredytów bankowych, najwięcej wskazań wystąpiło $\mathrm{w}$ przedsiębiorstwach realizujących umiarkowaną strategię gospodarowania kapitałem obrotowym $(91,7 \%)$.

Tabela 2. Źródła finansowania działalności w opinii zarządzających (\%)

\begin{tabular}{|c|c|c|c|c|c|c|c|}
\hline \multirow{3}{*}{ Wyszczególnienie } & \multicolumn{6}{|c|}{ Kryteria grupowania } & \multirow{3}{*}{ Średnio } \\
\hline & \multicolumn{3}{|c|}{$\begin{array}{c}\text { udział kapitału obrotowego } \\
\text { w aktywach (\%) }\end{array}$} & \multicolumn{3}{|c|}{$\begin{array}{c}\mathrm{ROE} \\
(\%)\end{array}$} & \\
\hline & I & II & III & I & II & III & \\
\hline a) Kapitał własny & 57,1 & 100,0 & 100,0 & 71,4 & 91,7 & 100,0 & 88,5 \\
\hline b) Kredyty bankowe długoterminowe & 85,7 & 91,7 & 85,7 & 71,4 & 91,7 & 100,0 & 88,5 \\
\hline c) Kredyty bankowe krótkoterminowe & 85,7 & 91,7 & 71,4 & 71,4 & 100,0 & 71,4 & 84,6 \\
\hline d) Pożyczki & 14,3 & 25,0 & 28,6 & 28,6 & 16,7 & 28,6 & 23,1 \\
\hline e) Dłużne papiery wartościowe & 0,0 & 25,0 & 0,0 & 14,3 & 16,7 & 0,0 & 11,5 \\
\hline f) Kredyt kupiecki & 85,7 & 83,3 & 71,4 & 85,7 & 91,7 & 57,1 & 80,8 \\
\hline g) Leasing & 42,9 & 58,3 & 57,1 & 57,1 & 58,3 & 42,9 & 53,8 \\
\hline h) Faktoring & 14,3 & 25,0 & 14,3 & 14,3 & 16,7 & 28,6 & 19,2 \\
\hline i) Venture capital & 0,0 & 0,0 & 0,0 & 0,0 & 0,0 & 0,0 & 0,0 \\
\hline j) Dotacje i subwencje & 42,9 & 33,3 & 57,1 & 42,9 & 50,0 & 28,6 & 42,3 \\
\hline
\end{tabular}

Źródło: opracowanie własne.

Wraz ze wzrostem wielkości wskaźnika ROE zwiększała się liczba wskazań, że kapitał własny oraz długoterminowe kredyty bankowe są źródłem finansowania działalności przedsiębiorstw (z 71,4\% do 100\%). Przedsiębiorstwa wykorzystywały kapitały umożliwiające długoterminowe inwestowanie, co w konsekwencji przyczy- 
niało się do uzyskiwania wyższej stopy zwrotu. Tendencję rosnącą wskazań, z 14,3\% do $28,6 \%$, odnotowano również w zakresie wykorzystania faktoringu. W przypadku krótkoterminowych kredytów bankowych oraz kredytu kupieckiego największa liczba wskazań dotyczyła grupy spółek osiągających przeciętną rentowność kapitału własnego, gdyż wszyscy zarządzający zadeklarowali, że korzystają z krótkoterminowych kredytów bankowych, natomiast 91,7\% z nich zaciągało kredyt kupiecki.

Jednym z podstawowych czynników wpływających na rozwój przedsiębiorstw jest dostęp do źródeł finansowania. Ponieważ nie zawsze występuje możliwość finansowania wewnętrznego, zarządzający przedsiębiorstwami poszukują zewnętrznych źródeł finansowania, z których mogłyby skorzystać. Według opinii pracowników Departamentu Stabilności Finansowej NBP w świetle przeprowadzonych przez różne ośrodki analiz, duże i średnie przedsiębiorstwa niefinansowe w Polsce nie napotykają istotnych barier $\mathrm{w}$ dostępie do finansowania. Jedną z zasadniczych przyczyn tego jest dobra sytuacja ekonomiczna tych przedsiębiorstw. Ponadto stabilna sytuacja sektora bankowego w Polsce ułatwia dostęp jednostek gospodarczych do zewnętrznych źródeł finansowania. Pomimo braku znaczących barier, Polska charakteryzuje się bardzo niskim poziomem wskaźnika relacji kredytu dla sektora przedsiębiorstw niefinansowych do Produktu Krajowego Brutto (PKB). Jedną z przyczyn tego może być ograniczona podaż projektów inwestycyjnych o satysfakcjonującej stopie zwrotu, jak również model hierarchii finansowania inwestycji, głównie kapitałami własnymi. Ponadto powodem mniejszego zadłużenia polskich przedsiębiorstw w bankach, zgodnie z teorią hierarchii, może być znaczny udział jednostek gospodarczych, będących własnością inwestorów zagranicznych, które mają na ogół dobry dostęp do zagranicznego finansowania wewnątrzgrupowego. Wyniki badań wskazują, że w przypadku mikro-, a nawet małych przedsiębiorstw, występuje ograniczony dostęp do finansowania zewnętrznego. Do głównych przyczyn tego stanu można zaliczyć krótką historię (także kredytową), niewielkie i nie zawsze dobrej jakości zabezpieczenia, słabą przejrzystość informacyjną tych podmiotów, ich niską przeżywalność, nierzadki brak wiedzy i doświadczenia menedżerów w pozyskiwaniu środków finansowych [NBP 2016, s. 4].

W tabeli 3 przedstawiono dostępność źródeł finansowania w opinii zarządzających. Przedstawicielom spółek proponowano uszeregowane warianty odpowiedzi na pytania, które zostały określone według następującej skali: 1 - źródło łatwo dostępne, 2 - źródło średnio dostępne, 3 - źródło trudno dostępne, 4 - źródło niedostępne. Za najtrudniej dostępne źródła finansowania zarządzający uznali dotacje i subwencje $(2,4)$ oraz venture capital $(2,4)$. Trudności w uzyskaniu funduszy pomocowych wynikają przede wszystkim ze skomplikowanych procedur, słabego dostępu do informacji oraz z braku wiary w możliwość pozyskania tych środków. Kolejną przeszkodą jest niemożność pozyskania wkładu własnego, co już na wstępie uniemożliwia znalezienie się w gronie beneficjentów. Z kolei dostęp do funduszy venture capital w Polsce nie jest powszechny. Możliwość uzyskania tej formy finansowania jest czasochłonna i wymaga znacznych nakładów pracy (należy zaznaczyć, iż 
nikt nie zadeklarował funduszu venture capital jako kapitałowego zasilenia przedsiębiorstwa). Do najłatwiej dostępnych źródeł finansowania według wskazań zarządzających zaliczono leasing $(1,1)$, faktoring $(1,2)$, kredyty bankowe krótkoterminowe $(1,2)$ oraz kredyty bankowe długoterminowe $(1,3)$. Stwierdzono pewne zależności pomiędzy oceną dostępności danego źródła finansowania (będącego znaczącym kapitałem pochodzenia środków gospodarczych) a znaczeniem w finansowaniu działalności. Kapitał własny pod tym względem był trudniej dostępnym źródłem finansowania w przedsiębiorstwach realizujących strategię agresywną w zakresie kapitału obrotowego $(1,7)$ niż w spółkach o strategiach umiarkowanych $(1,6)$ i konserwatywnych $(1,6)$. Odwrotna zależność wystąpiła w przypadku kredytu kupieckiego. Zobowiązania z tytułu dostaw i usług były trudniej dostępnym źródłem finansowania w przedsiębiorstwach realizujących strategię konserwatywną $(1,9)$ niż w spółkach o strategiach umiarkowanych $(1,6)$ i agresywnych $(1,6)$. Kredyty bankowe (długoi krótkoterminowe) były natomiast łatwiej dostępnym źródłem pochodzenia aktywów w spółkach realizujących strategię umiarkowaną (odpowiednio 1,2 i 1,1) niż w tych o skrajnych strategiach gospodarowania kapitałem obrotowym.

Tabela 3. Dostępność źródeł finansowania w opinii zarządzających

\begin{tabular}{|c|c|c|c|c|c|c|c|}
\hline \multirow{3}{*}{ Wyszczególnienie } & \multicolumn{6}{|c|}{ Kryteria grupowania } & \multirow{3}{*}{ Średnio } \\
\hline & \multicolumn{3}{|c|}{$\begin{array}{c}\text { udział kapitału obrotowego } \\
\text { w aktywach (\%) }\end{array}$} & \multicolumn{3}{|c|}{$\begin{array}{c}\mathrm{ROE} \\
(\%) \\
\end{array}$} & \\
\hline & I & II & III & I & II & III & \\
\hline a) Kapitał własny & 1,7 & 1,6 & 1,6 & 1,9 & 1,6 & 1,4 & 1,6 \\
\hline b) Kredyty bankowe długoterminowe & 1,6 & 1,2 & 1,3 & 1,7 & 1,2 & 1,1 & 1,3 \\
\hline c) Kredyty bankowe krótkoterminowe & 1,3 & 1,1 & 1,3 & 1,4 & 1,0 & 1,3 & 1,2 \\
\hline d) Pożyczki & 1,6 & 1,8 & 1,7 & 1,4 & 1,8 & 1,7 & 1,7 \\
\hline e) Dłużne papiery wartościowe & 1,9 & 1,8 & 2,0 & 1,7 & 1,8 & 2,0 & 1,8 \\
\hline f) Kredyt kupiecki & 1,6 & 1,6 & 1,9 & 1,6 & 1,5 & 2,0 & 1,7 \\
\hline g) Leasing & 1,1 & 1,1 & 1,0 & 1,1 & 1,1 & 1,0 & 1,1 \\
\hline h) Faktoring & 1,3 & 1,3 & 1,1 & 1,3 & 1,3 & 1,1 & 1,2 \\
\hline i) Venture capital & 2,4 & 2,5 & 2,3 & 2,4 & 2,3 & 2,6 & 2,4 \\
\hline j) Dotacje i subwencje & 2,0 & 2,8 & 2,1 & 2,3 & 2,3 & 2,7 & 2,4 \\
\hline
\end{tabular}

Źródło: opracowanie własne.

W miarę wzrostu poziomu wskaźnika ROE stabilne źródła finansowania działalności gospodarczej, a więc kapitały własne oraz długoterminowe kredyty bankowe, były oceniane przez zarządzających jako łatwiej dostępne (w przypadku kapitałów własnych nastąpił spadek z 1,9 do 1,4, natomiast w zakresie długoterminowych kredytów bankowych - z 1,7 do 1,1). Zobowiązania krótkoterminowe, będące znaczącym źródłem finansowania, głównie w formie kredytów bankowych krótkoterminowych oraz kredytów kupieckich, zostały ocenione jako najłatwiej dostępne źródła finansowania w przypadku przedsiębiorstw uzyskujących przeciętną rentowność 
sprzedaży (1 i 1,5). Tendencję rosnącą wskazań odnotowano w przypadku emisji dłużnych papierów wartościowych. Im wyższa była rentowność kapitałów własnych, tym w większym stopniu zarządzający stwierdzali, iż jest to trudniej dostępne źródło finansowania - nastąpił wzrost oceny z 1,7 do 2,0.

Tabela 4 zawiera informacje dotyczące kosztów pozyskania kapitału w opinii zarządzających. Najwięcej przedstawicieli spółek (średnio 50\%) stwierdziło, iż najdroższym źródłem finansowania jest kapitał własny. Decyduje o tym koszt alternatywny tego kapitału (średnio 50\% wskazań), który stanowi wartość utraconych możliwości, które spółki mogłyby uzyskać, decydując się na alternatywę, odznaczającą się pewnym poziomem rentowności. Przedsiębiorstwa nie wykorzystują w najlepszy sposób swoich zasobów, zamrażając kapitał w inwestycjach rzeczowych, co przyczynia się do zmniejszenia efektywności działania. Średnio $26,9 \%$ przedstawicieli spółek zadeklarowało, że najdroższym źródłem pochodzenia kapitału są długoterminowe kredyty bankowe, natomiast średnio 7,7\% wskazało na krótkoterminowe kredyty bankowe. Jednocześnie średnio $11,5 \%$ badanych uznało faktoring jako najdroższe źródło kapitału. Koszt kredytu i faktoringu składa się z dwóch elementów, tj. prowizji i odsetek. Średnio 46,2\% przedstawicieli spółek stwierdziło, iż to głównie odsetki decydują o kosztach danego źródła finansowania, a średnio $11,5 \%$ zarządzających wskazało na koszty związane z zawarciem umów dotyczących korzystania z kapitału obcego. Bieniasz i Czerwińska-Kayzer [2008, s. 93], porównując koszty obu źródeł finansowania, stwierdziły, iż koszt faktoringu jest tylko pozornie wysoki. Co prawda, odsetki liczone są według wyższej stopy procentowej niż przy kredycie obrotowym, jednak rozkładają się często na dodatkowe usługi, które mogą być przyczyną obniżenia innych kosztów w przedsiębiorstwie, np. kosztów administracyjnych czy strat z tytułu należności nieściągalnych.

Kapitał własny był częściej wskazywany jako najdroższe źródło finansowania działalności w przedsiębiorstwach realizujących skrajne polityki gospodarowania kapitałem obrotowym $(57,1 \%)$ niż w przypadku spółek o strategii umiarkowanej $(41,7 \%)$. Odnotowano tendencję malejącą między liczbą wskazań na to źródło finansowania, wraz ze zwiększeniem wskaźnika ROE - z 57,1\% do 42,9\% wskazań. W miarę wzrostu wskaźnika udziału kapitału obrotowego w aktywach malała liczba wskazań, iż kredyty bankowe długoterminowe są najdroższym źródłem finansowania (z 42,9\% do 14,3\%), zwiększała się natomiast liczba wskazań na kredyty bankowe krótkoterminowe (do 14,3\%). Ponadto kredyty bankowe długoterminowe były częściej wskazywanym źródłem finansowania w przedsiębiorstwach osiągających najniższą oraz najwyższą rentowność kapitałów własnych (28,6\%) niż w przypadku spółek o przeciętnej wielkości wskaźnika ROE (25\%). Tendencję malejącą odnotowano w przypadku krótkoterminowych kredytów bankowych, gdyż wraz ze wzrostem rentowności kapitałów własnych malała liczna wskazań na to źródło finasowania jako na źródło najdroższe. Tendencję rosnącą znaczenia stwierdzono w przypadku faktoringu. Co prawda, nie odnotowano wskazań na to źródło finansowania w przedsiębiorstwach o najniższym wskaźniku ROE, jednak $28,6 \%$ przedstawicieli 
Tabela 4. Koszty pozyskania kapitału w opinii zarządzających

\begin{tabular}{|c|c|c|c|c|c|c|c|}
\hline \multirow{3}{*}{ Wyszczególnienie } & \multicolumn{6}{|c|}{ Kryteria grupowania } & \multirow{3}{*}{ Średnio } \\
\hline & \multicolumn{3}{|c|}{\begin{tabular}{|c|} 
udział kapitału obrotowego \\
w aktywach (\%)
\end{tabular}} & \multicolumn{3}{|c|}{$\begin{array}{c}\mathrm{ROE} \\
(\%)\end{array}$} & \\
\hline & $\mathrm{I}$ & II & III & I & II & III & \\
\hline \multicolumn{8}{|c|}{ Które źródło finansowania działalności jest najdroższe? } \\
\hline a) Kapitał własny & 57,1 & 41,7 & 57,1 & 57,1 & 50,0 & 42,9 & 50,0 \\
\hline b) Kredyty bankowe długoterminowe & 42,9 & 25,0 & 14,3 & 28,6 & 25,0 & 28,6 & 26,9 \\
\hline c) Kredyty bankowe krótkoterminowe & 0,0 & 8,3 & 14,3 & 14,3 & 8,3 & 0,0 & 7,7 \\
\hline d) Pożyczki & 0,0 & 0,0 & 0,0 & 0,0 & 0,0 & 0,0 & 0,0 \\
\hline e) Dłużne papiery wartościowe & 0,0 & 0,0 & 0,0 & 0,0 & 0,0 & 0,0 & 3,8 \\
\hline f) Kredyt kupiecki & 0,0 & 0,0 & 0,0 & 0,0 & 0,0 & 0,0 & 0,0 \\
\hline g) Leasing & 0,0 & 8,3 & 0,0 & 0,0 & 8,3 & 0,0 & 0,0 \\
\hline h) Factoring & 0,0 & 16,7 & 14,3 & 0,0 & 8,3 & 28,6 & 11,5 \\
\hline i) Venture capital & 0,0 & 0,0 & 0,0 & 0,0 & 0,0 & 0,0 & 0,0 \\
\hline j) Dotacje i subwencje & 0,0 & 0,0 & 0,0 & 0,0 & 0,0 & 0,0 & 0,0 \\
\hline \multicolumn{8}{|c|}{ Co decyduje o tym, że wybrane w przedsiębiorstwie źródło finansowania jest najdroższe? } \\
\hline a) Koszt alternatywny kapitału własnego & 57,1 & 41,7 & 57,1 & 57,1 & 50,0 & 42,9 & 50,0 \\
\hline $\begin{array}{l}\text { b) Odsetki z tytułu korzystania } \\
\text { z zewnętrznych źródeł finansowania }\end{array}$ & 42,9 & 50,0 & 42,9 & 42,9 & 41,7 & 57,1 & 46,2 \\
\hline $\begin{array}{l}\text { c) Koszty związane z zawarciem umów } \\
\text { dotyczących korzystania z kapitału } \\
\text { obcego }\end{array}$ & 0,0 & 16,7 & 14,3 & 0,0 & 8,3 & 28,6 & 11,5 \\
\hline $\begin{array}{l}\text { a) Koszt dyskonta lub premii związany } \\
\text { z pozyskaniem środków pieniężnych }\end{array}$ & 0,0 & 8,3 & 14,3 & 0,0 & 16,7 & 0,0 & 7,7 \\
\hline b) Ujemne różnice kursowe & 14,3 & 0,0 & 14,3 & 14,3 & 8,3 & 0,0 & 7,7 \\
\hline
\end{tabular}

Źródło: opracowanie własne.

przedsiębiorstw osiągających najwyższą rentowność kapitałów własnych stwierdziło, iż jest to najdroższe źródło finansowania działalności.

Analizując czynniki wpływające na poziom kosztów danego źródła finansowania, należy zauważyć, iż zarządzający przedsiębiorstwami realizującymi skrajne strategie gospodarowania kapitałem obrotowym stwierdzili, iż główną determinantą jest koszt alternatywny kapitału własnego (57,1\% wskazań), natomiast przedstawiciele spółek o strategii umiarkowanej byli zdania, iż decydujące są odsetki z tytułu korzystania z zewnętrznych źródeł finansowania. W miarę wzrostu wielkości wskaźnika ROE malała liczba wskazań, że koszt alternatywny decyduje o skali kosztów danego źródła finansowania. Przedsiębiorstwa efektywniej wykorzystywały kapitał własny, w związku z tym ponosiły niższe koszty utraconych korzyści. W przypadku odsetek z tytułu korzystania z zewnętrznych źródeł finansowania oraz kosztów związanych z zawarciem umów, dotyczących wykorzystania kapitału obcego, największa liczba wskazań wystąpiła w spółkach najbardziej rentownych i wyniosła odpo- 
wiednio $57,1 \%$ w odniesieniu do kosztu alternatywnego kapitału własnego oraz 28,6\% w przypadku kosztów związanych z zawarciem umów. Przedsiębiorstwa, chcąc stać się bardziej konkurencyjne, muszą rozwijać się i korzystać z zewnętrznych źródeł finansowania, co związane jest z ponoszeniem kosztów z tytułu posiadania dodatkowego kapitału.

\section{Wnioski}

W opracowaniu przedstawiono opinie zarządzających dotyczące źródeł finansowania działalności w przedsiębiorstwach przemysłowych. Na podstawie przeprowadzonych badań sformułowano następujące wnioski:

1. Zarządzający przedsiębiorstwami przemysłowymi stosują zróżnicowane formy finansowania działalności. Najwięcej przedstawicieli spółek wskazało, iż finansuje działalność stabilnymi źródłami finansowania, a więc kapitałem własnym i długoterminowymi kredytami bankowymi, co jest zgodne z założeniami teorii hierarchii źródeł finansowania. Ponadto większość zarządzających korzysta z krótkoterminowego kredytu bankowego i kupieckiego. Przedsiębiorstwa dążą zatem do uzyskania optymalnych rezultatów, gdyż zaangażowanie zarówno kapitałów stałych, jak i zobowiązań krótkoterminowych, pozwala na minimalizację ryzyka związanego z utratą płynności finansowej oraz zmniejszenie kosztów wykorzystania kapitału.

2. Duże i średnie przedsiębiorstwa niefinansowe w Polsce nie napotykają istotnych barier $\mathrm{w}$ dostępie do zewnętrznego finansowania działalności. Za najtrudniej dostępne źródła finansowania zarządzający uznali dotacje i subwencje oraz venture capital. Do najłatwiej dostępnych źródeł kapitału zaliczono leasing, faktoring, kredyty bankowe krótkoterminowe i długoterminowe.

3. Najwięcej przedstawicieli spółek stwierdziło, iż najdroższym źródłem finansowania, ze względu na koszt alternatywny, jest kapitał własny. Zarządzający przedsiębiorstwami przemysłowymi mają zatem świadomość, że aby stać się bardziej konkurencyjni, muszą rozwijać się i korzystać z zewnętrznych źródeł finansowania, co potwierdzają założenia teorii podatkowych. Na dalszych pozycjach pod tym względem zarządzający wymieniali długoterminowe i krótkoterminowe kredyty bankowe oraz faktoring. Przedstawiciele spółek zadeklarowali, iż to głównie odsetki decydują o skali kosztów zewnętrznych źródeł finansowania. Jednocześnie jednak odsetki te pozwalają na uzyskanie dodatniego efektu dźwigni finansowej.

\section{Literatura}

Bartkiewicz A., 2004, Wptyw strategii finansowania majątku obrotowego na płynność finansowa na przykładzie spółek giełdowych przemystu lekkiego, [w:] Pluta W. (red.), Zarzadzanie finansami firmy - teoria i praktyka, Wydawnictwo Akademii Ekonomicznej we Wrocławiu, Wrocław.

Bieniasz A., Czerwińska-Kayzer D., 2008, Faktoring jako źródło finansowania działalności bieżacej przedsiębiorstwa, Zeszyty Naukowe SGGW - Ekonomika i Organizacja Gospodarki Żywnościowej, nr 66, Warszawa. 
Błach J., 2009, Ewolucja teorii struktury kapitatu, Finanse, nr 1.

Churchill N.C., Lewis V.L., 1983, The Five Stages of Small Business Growth, Harvard Business Review, vol. 61 .

Czekaj J., Dresler Z., 2005, Zarzadzanie finansami przedsiębiorstw - podstawy teorii, PWN, Warszawa. Damodaran A., 2007, Finanse korporacyjne. Teoria i praktyka, Wydawnictwo Helion, Gliwice.

Duliniec A., 2007, Finansowanie przedsiębiorstwa, PWE, Warszawa.

Gajdka J., 2002, Teorie struktury kapitalu i ich aplikacja w warunkach polskich, Uniwersytet Łódzki, Łódź.

Gajdka J., Walińska E., 1998, Zarządzanie finansowe. Teoria i praktyka, Fundacja Rozwoju Rachunkowości w Polsce, Warszawa.

Gawrońska Z., Makarska A., 2012, Wpływ struktury kapitalu na wartość przedsiębiorstwa, Nierówności społeczne a wzrost gospodarczy, nr 27, Rzeszów.

Łukasik G., Naczyński D., 2015, Rola struktury kapitału w ksztattowaniu wartości przedsiębiorstwa (elementy teorii, doświadczenia, praktyki), Zeszyty Naukowe SGGW - Ekonomika i Organizacja Gospodarki Żywnościowej, nr 112, Warszawa.

Myers S.C., 1984, The capital structure puzzle, Journal of Finance, 39, nr 3.

Modigliani F., Miller, M., 1958, The cost of capital, corporation finance and the theory of investment, American Economic Review, vol. 48.

NBP, 2016, Dostępność finansowa przedsiębiorstw niefinansowych w Polsce, Departament Stabilności Finansowej NBP, Warszawa.

Waga M., 2014, Źródła finansowania małych $i$ średnich przedsiębiorstw, INFOS Zagadnienia społeczno-gospodarcze, Wydawnictwo Sejmowe dla Biura Analiz Sejmowych, nr 7(167), Warszawa.

Wasilewski M., Pisarska A., 2009, Źródła finansowania działalności małych i średnich przedsiębiorstw, Zeszyty Naukowe SGGW w Warszawie - Ekonomika i Organizacja Gospodarki Żywnościowej, nr 77, Warszawa.

Wasilewski M., Zabadała P., 2015, Wybór źródeł finansowania w opiniach zarzadzajacych przedsiębiorstwami rolniczymi, Studia i Materiały, Miscellanea Oeconomicae, R. 19, nr 3, UJK w Kielcach.

Wędzki D., 2003, Strategie płynności finansowej przedsiębiorstwa, przepływy pieniężne a wartość dla właścicieli, Oficyna Ekonomiczna, Kraków.

Zalewski H., 1998, Finanse firmy w spótkach i innych podmiotach gospodarczych, Ośrodek Doradztwa i Doskonalenia Kadr, Gdańsk. 